NBER WORKING PAPER SERIES

\title{
HETEROGENEITY AND THE FDI VERSUS \\ EXPORT DECISION OF JAPANESE MANUFACTURERS
}

\author{
Keith Head \\ John Ries \\ Working Paper 10052 \\ http://www.nber.org/papers/w10052
NATIONAL BUREAU OF ECONOMIC RESEARCH 1050 Massachusetts Avenue
Cambridge, MA 02138
October 2003

We thank Kyoji Fukao, Jota Ishikawa, an anonymous referee, and participants at the 15th Annual TRIO Conference held in Tokyo, December 10-11, 2002 for their helpful comments. The views expressed herein are those of the authors and not necessarily those of the National Bureau of Economic Research.

(C)2003 by Keith Head and John Ries. All rights reserved. Short sections of text, not to exceed two paragraphs, may be quoted without explicit permission provided that full credit, including (C notice, is given to the source. 
Heterogeneity and the FDI versus Export Decision of Japanese Manufacturers

Keith Head and John Ries

NBER Working Paper No. 10052

October 2003

JEL No. F120, F230

\section{ABSTRACT}

We investigate whether productivity differences explain why some manufacturers sell only to the domestic market while others serve foreign markets through exports and/or FDI. When overseas production offers no cost advantages, our model predicts that investors should be more productive than exporters. An extension allowing for low-cost foreign production can reverse this prediction. Data for 1070 large Japanese firms reveal that firms that invest abroad and export are more productive than firms that just export. Among overseas investors, more productive firms span a wider range of host-country income levels.

Keith Head

Sauder School of Business

University of British Columbia

2053 Main Mall

Vancouver, BC V6T1Z2

keith.head@ubc.ca

John Ries

Sauder School of Business

University of British Columbia

2053 Main Mall

Vancouver, BC V6T1Z2

john.ries@ubc.ca 


\section{Introduction}

Theoretical and empirical research has revealed the factors that underlie the decision of firms to serve foreign consumers through foreign direct investment (FDI) or exporting. Evidence shows that firms prefer FDI to exporting when trade costs are high and plantlevel scale economies are low. In any given industry, however, we observe that some firms engage in FDI, some export, and some do neither. There is limited understanding of heterogeneous actions of firms facing the same trade and investment opportunities.

This paper builds on research of Helpman, Melitz, and Yeaple (forthcoming), hereafter HMY, examining the role of differences in the productivity levels of firms in an industry as explanations for the presence of purely domestic firms, exporting firms, and investing firms. We develop an alternative model that yields the predictions found by HMY and then test these predictions. We also extend the model and show that the ordering predicted by HMY can be reversed if the foreign country is the low-cost production site. We categorize 1070 publicly traded Japanese firms in 1989 into groups according to whether they export and have foreign direct investment. Then we use various measures of the productivity of these firms to investigate productivity differences across these groups.

Our analysis contributes to the literature investigating the export versus FDI decision of firms. Brainard (1997) shows how trade costs, market size, and plant-level economies of scale interact to explain the export and FDI decision of firms producing differentiated products. She shows that the share of firms that export in an industry is an increasing function of scale economies and a decreasing function of trade costs and foreign market size. Using U.S. exports and foreign affiliate sales data for 63 industries in 27 countries, 
Brainard finds that export shares decrease with trade and freight costs and increase with plant-level scale economies.

Brainard identifies a possible equilibrium where some firms export and others do foreign investment. Her theory, however, simply specifies the share of firms doing each activity and does not predict which firms do which activity. HMY extend this line of research by identifying a role for productivity differences to explain the choice. HMY develop a free entry model where firms have heterogeneous productivity levels and each produce a differentiated product. Consumers have CES preferences and goods are subject to "iceberg" transportation costs. They find that the least productive firms do not serve the foreign market, the most productive firms engage in FDI, and the midrange firms export. Their paper extends Melitz (forthcoming) that shows that only the most productive firms in an industry export. Bernard, Eaton, Jenson, and Kortum (2003) use a Ricardian model of trade in differentiated products and demonstrate that the most productive firms in an industry export. Neither of the latter papers consider the option to reach foreign consumers through direct investment.

Bernard and Jenson (1999) measure the total factor productivity (TFP) of U.S. manufacturing plants over the period 1984-1992. They find that exporting plants exhibit higher TFP than non-exporters (after controlling for industry and state fixed effects) and productive plants are most likely to become exporters. Bernard and Jenson also investigate whether exporting "causes" greater TFP by examining productivity growth of exporters and non-exporters. Their results showing that exporters have significantly slower TFP growth than non-exporters do not support the proposition that exporting generates TFP growth. HMY analyze the relationship between the export to FDI ratio 
of 4-digit U.S. manufacturing industries and the dispersion of sales levels in these industries and find support for their model. Girma and Kneller (2003) test the predictions of HMY using data on 5,332 firms in the United Kingdom. Based on tests of stochastic dominance, they find support for the proposition that the productivity distribution of multinationals dominates that of export firms which dominates that of non-exporters.

We extend both the theoretical and empirical literature. The next section develops a simple linear demand model that generates the HMY predictions under the assumption that factors prices are equal and that firms serve foreign consumers either by exporting or opening up a new manufacturing facility in the foreign country. Section 3 explains how we classify the 1070 Japanese manufacturing firms into four groups and identifies the different ways we measure productivity. It goes on to examine differences in productivity across the groups of firms to test the predictions of our model in the case of equal wages. Section 4 considers international factor price differences and the possibility that firms may choose to close down the home plant when they invest abroad. We find that low productivity firms are the ones most attracted to the option of relocating to a lowcost foreign country. Data on host-country incomes reveal that low productivity firms invest primarily in low-income countries. The final section summarizes our findings.

\section{Theoretical Predictions of the Basic Model}

We provide a simple theoretical model that generates predictions that can be tested with our data. It replicate's HMY's predictions on the ordering of productivity across firms that sell only to the domestic market and those that serve foreign markets through ex- 
ports and/or FDI. Our analysis, therefore, reveals that their theoretical results do not rely upon their assumptions of CES preferences and iceberg transportation costs.

We evaluate firm $i$ producing a differentiated product that is deciding whether to serve a foreign market $f$ and, if so, whether to export or invest abroad (FDI). A third way to serve the foreign market would be to license the production process or brand to a foreign firm. Firm-level data on licensing by Japanese firms are not available. Aggregate Japanese data suggest that exporting and direct investment are the primary modes through which Japanese firms serve foreign markets: For 2001, the Bank of Japan reports exports of 46.6 trillion yen, a stock of direct investment abroad of 39.6 trillion yen, and total royalties and license fees of just 1.3 trillion yen. For these reasons, we do not consider the possibility of licensing in the ensuing analysis.

We assume that marginal costs are constant and equal to $w / A_{i}$ where $w$ represents wages in the country where the goods are produced and $A_{i}$ is a measure of productivity that is specific to firm $i$ and varies across firms. The firm evaluates the profits of exporting and foreign investment and chooses the mode that generates the highest profits.

We assume the following quadratic utility function for consumers:

$$
U=Q_{0}+\sum_{i=1}^{N}\left[Q_{i}-(1 / 2) Q_{i}^{2}\right] .
$$

Products $i=1 \ldots N$ are each manufactured by a single firm whereas $Q_{0}$ is a competitively supplied numeraire good. Utility maximization yields a linear demand for firm $i^{\prime}$ s product: $P_{i}=1-Q_{i}$, for $i \geq 1$. Thus, this set-up allows us to model each firm's decision as if it were a monopolist facing a linear demand curve. We therefore omit the firm 
subscripts in the rest of the derivation. Obviously these assumptions are not designed for realism but rather to examine the FDI versus export decision in a truly "minimal" model of the market.

Exports incur a per unit trade cost of $\tau$ whereas FDI allows the firm to avoid trade costs but requires a fixed cost $K$ to operate the facility. As this model is static, $K$ comprises reoccurring expenses that do not vary with output as well as sunk costs incurred when the plant is opened.

If a firm chooses to neither export nor do FDI it earns zero profits in the foreign market. We assume equal wages of $w$ in the home and foreign country, an assumption that yields the same result as HMY regarding the ordering of productivity across types of firms. With equal wages, the profits from exporting, $\pi_{X}$, and FDI, $\pi_{I}$, are given by

$$
\begin{aligned}
& \pi_{X}=[(1-(w / A)-\tau) / 2]^{2}, \\
& \pi_{I}=[(1-(w / A)) / 2]^{2}-K .
\end{aligned}
$$

Figure 1 displays the profits associated with each choice for different levels of $A{ }^{1}$ Unproductive firms, those with low realizations of $A$, neither export nor engage in FDI because they cannot sell for a price lower than the "choke" price or afford the fixed costs of FDI. The figure also shows that highly productive firms prefer FDI to exports.

Figure 1 shows the critical level of $A$ that makes each mode preferable. The critical

\footnotetext{
${ }^{1}$ We generate the figure based on parameter values of $\tau=.15, w=.5$, and $K=.05$.
} 
Figure 1: Productivity and the profits of exporting $\left(\Pi_{X}\right)$ and FDI $\left(\Pi_{I}\right)$

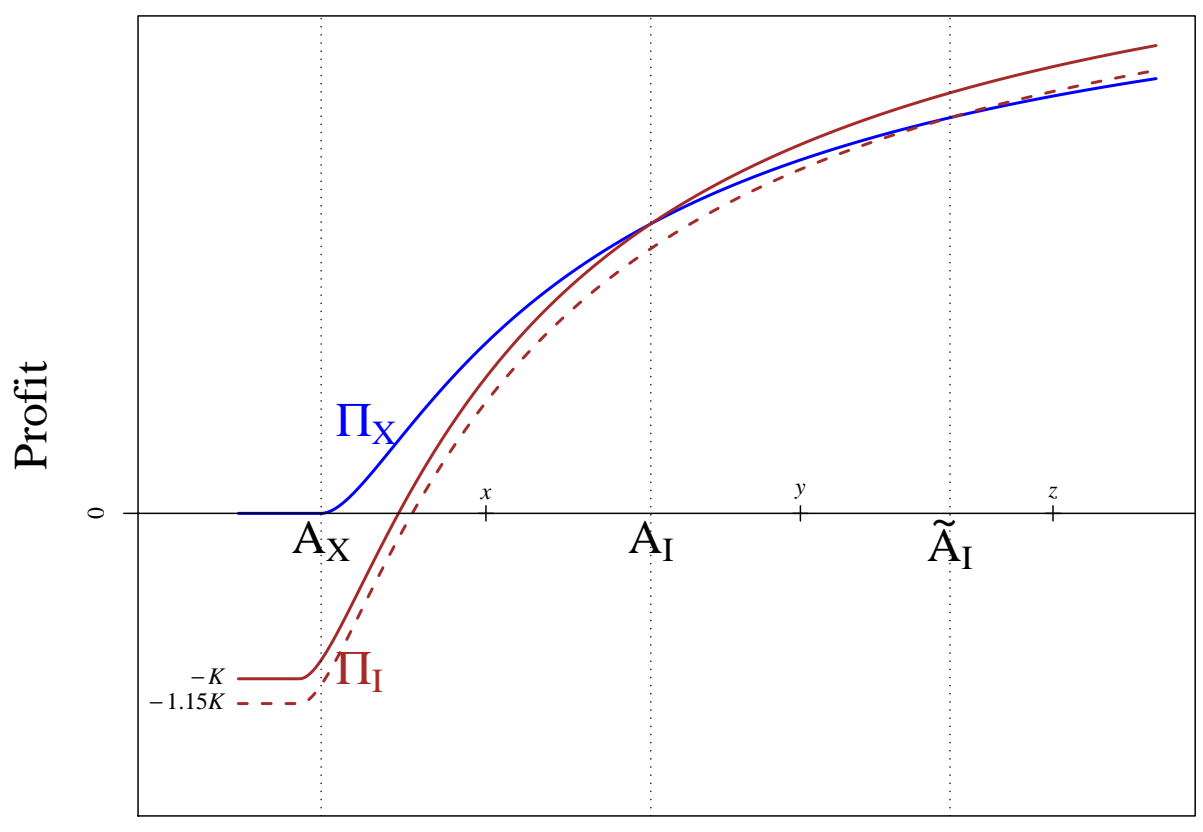

Productivity (A)

productivity levels for exporting, $A_{X}$, and FDI, $A_{I}$, are

$$
A_{X}=w /(1-\tau) \text { and } A_{I}=w\left[\frac{2 \tau}{2 \tau-4 K-\tau^{2}}\right]
$$

The equalities reveal a few intuitive comparative statics. First, rising trade costs increase the critical productivity required to make exporting profitable. Second, higher trade costs lower the critical productivity necessary to make FDI preferred to exporting. ${ }^{2}$ Finally, a higher fixed cost of operating foreign affiliates increases the level of productivity necessary for FDI to be more profitable than exporting.

The model outlined above considers a single foreign market. However, firms have

\footnotetext{
${ }^{2}$ This comparative static requires that $K-\tau^{2}>0$ which is always met if exporting is the most profitable strategy for some level of productivity.
} 
the opportunity to sell to consumers in different foreign countries. Our data set does not contain information on the destination of each firm's exports. Thus, we are interested in aggregate exports and FDI. Fixed costs of investment vary across destination countries for a number of reasons. Countries with high crime rates and political rebellions increase security costs. Markets where corruption is rife might also require bribes. Fixed costs could reflect expatriate staffing necessary to implement modern management techniques. In distant and unfamiliar markets, substantial costs might also be required to gather intelligence and identify optimal production sites.

The dashed line in Figure 1 shows the profits associated with FDI when fixed costs are increased and portrays how a higher critical level of productivity, denoted $\tilde{A}_{I}$, is necessary to make FDI preferable. Consider firms with productivity levels corresponding to points $x, y$, and $z$. Firm $x$ exports to both markets, Firm $y$ exports to the high fixed-cost country and invests in the other country, and Firm $z$ invests in both foreign countries. Aggregating across markets will yield many firms that do both FDI and exporting.

Our simple model generates the same testable prediction that HMY generate in their model. Namely, firms that serve only the domestic market, firms that export, firms that export and do FDI, and firms that serve foreign consumers only through FDI are ordered according to their productivity levels.

\section{Testing the Model Predictions}

The first subsection describes the data and the proxies we use for firm productivity. The second subsection tests the predictions of the basic model. 


\subsection{Data and productivity measures}

We employ data for 1070 publicly listed Japanese manufacturing firms. Exports, sales, finished goods purchases, material purchases, depreciable assets, and labour costs are available from the financial statements of publicly traded companies in Japan. The firms are classified into 17 2-digit industries and 88 5-digit industries (the appendix contains a list of these industries). Toyo Keizai (1992) compiles information on the overseas affiliates of Japanese companies based on a survey conducted in 1991. They list the host country, number of employees, date of establishment, equity share, and type of investment (greenfield or acquisition).

We classify these firms into four groups based on 1989 characteristics. We use D to represent firms that only serve the domestic market. DX also firms export, DXI firms export and invest abroad, and DI firms have FDI but do not export. Table 1 provides information on these groups. The largest group is DXI with 459 firms accounting for $80 \%$ of the domestic employment of the 1070 firms. The next largest group is the firms that export but do not do FDI. There are more firms that sell only to the domestic market than those that sell to the domestic market and have overseas affiliates but the latter group comprises larger firms. The table reveals that $\mathrm{D}$ firms are the smallest in terms of average sales, average value added, and average employment whereas DXI firms are the largest. DX and DI firms lie in between in terms of size with DI being somewhat larger of the two.

Our theory predicts that there will be an ordering of our four groups according to productivity. Namely, D firms should be the least productive, followed by DX firms, then DXI firms, with DI firms being the most productive. To test this prediction, we 
Table 1: Characteristics by firm type

\begin{tabular}{lrrrrr}
\hline Type & Firms & Sales & VA & Emps. & Emps. \\
& $\#$ & Avg. (m. Y) & Avg. (m. Y) & Avg. & Share \\
Domestic sales only (D) & 192 & 36490 & 14428 & 627 & $4 \%$ \\
Dom. sales and exports, (DX) & 375 & 43589 & 19489 & 880 & $12 \%$ \\
Dom. sales, exports, and FDI (DXI) & 459 & 250690 & 108319 & 4659 & $80 \%$ \\
Dom. sales and FDI (DI) & 44 & 134493 & 55403 & 2276 & $4 \%$ \\
\hline
\end{tabular}

must measure firm-level productivity. Our model, as well as that of HMY, predicts a monotonic relationship between firm output and productivity. This is because productive firms have lower unit costs, charge lower prices, and therefore sell more. Since the monopolist always prices in the elastic proportion of the demand curve, the value of sales will increase with productivity. Accordingly, we use sales as well as two other measures of firm size — value added and employment—as proxies for productivity. We calculate value added as the difference between sales and the sum of finished goods and materials purchases. We also subtract exports from sales and value added to avoid "accounting" relationships between these measures and firm types DX and DXI that reflect export activities. Thus, these measures indicate size in the domestic market. ${ }^{3}$ We cannot, however, adjust employment and thus it reflects employment for both domestic and export sales.

We also estimate productivity three ways by utilizing firm-level information on output and factor inputs. Following Griliches and Mairesse (1990) we measure "approxi-

\footnotetext{
${ }^{3}$ There are 64 cases where subtracting exports from value-added generates negative numbers. These are firms that purchase finished goods that they sell abroad. To see this, consider a firm that only purchases finished goods for export. Calculating value added as sales-(exports+finished goods) yields a negative number.
} 
mate total factor productivity" as:

$$
\mathrm{ATFP} \equiv \ln Q / L-s \ln K / L .
$$

Intuitively, this productivity measure starts with average labor productivity, $Q / L$, and adjusts for capital intensity $K / L$. Parameter $s$ measures the importance of capital in the production function and can vary between zero, where productivity equals labor productivity, and one, where productivity is given by capital productivity $(Q / K)$. In the empirical implementation we follow Hall and Jones (1999) in setting $s=1 / 3$.

The drawback to ATFP is that it reflects both "true" technical efficiency as well as scale economies. To see this, consider a Cobb-Douglas production function given by $Q=A\left[K^{\omega} L^{(1-\omega)}\right]^{\mu}$. We can relate our measure of productivity, ATFP, to the true technical efficiency parameter, denoted $A$,

$$
\mathrm{ATFP}=\ln A+(\mu \omega-s) \ln K+(\mu(1-\omega)-(1-s)) \ln L .
$$

Technical efficiency equals ATFP when $\mu \omega=s$ and $\mu(1-\omega)=1-s$. This occurs when there are constant returns to scale $(\mu=1)$ and $s$ equals the true capital cost share, $\omega$.

Substituting the cost minimization condition $s=\omega$ and manipulating, we arrive at

$$
\mathrm{ATFP}=(1 / \mu) \ln A+\left(\frac{\mu-1}{\mu}\right) \ln Q .
$$

The productivity measure ATFP varies with true technical efficiency and scale. The 
theory pertains to technical efficiency. Firms with high technical efficiency will export or invest abroad. Exporting will increase the scale of home operations whereas FDI might lower it if it displaces production for export. ATFP will be a good measure of technical efficiency if there are constant returns to scale and $s=1 / 3$ is a reasonable measure of the cost share of capital.

We also measure productivity by estimating the following four-factor Cobb-Douglas production function

$$
\ln Q_{i t}=\ln A_{t}+\beta_{M} \ln M_{i t}+\beta_{K} \ln K_{i t}+\beta_{S} \ln S_{i t}+\beta_{U} \ln U_{i t}+\epsilon_{i t} .
$$

where $Q$ is a measure of output and $M, K, S$, and $U$, represent materials, capital, skilled workers, and unskilled workers.

Output is sales minus purchased finished goods. We measure capital as the stock of depreciable assets (buildings, machinery, and equipment). To allow for heterogeneity across workers in a firm, we consider two types of labour inputs-production (termed unskilled, $U$ ) and nonproduction workers (termed skilled, $S$ ). We have data on total compensation paid to each category of employees. We deflate production wages by the average wage paid to workers with high school degrees in Japan to obtain a measure of production worker inputs. Similarly, to measure nonproduction worker inputs, we deflate total salaries of selling, general and administrative (SGA) employees by the average salary paid to university graduates. We deflate nominal output by the wholesale price index. Price indices are available at roughly the 2-digit industry level. We deflate depreciable assets by the Japanese capital goods deflator. To deflate materials, we 
Table 2: Industry-level (2-digit) production function estimates

\begin{tabular}{lrcc}
\hline Industry & \# Firms & Scale economies $(\mu)$ & Capital share $(\omega)$ \\
Food & 92 & 1.01 & 0.53 \\
Textile & 78 & 0.96 & 0.22 \\
Pulp and paper & 31 & 1.01 & 0.26 \\
Chemicals & 133 & 0.98 & 0.48 \\
Pharmaceuticals & 34 & 0.97 & 0.32 \\
Petroleum & 10 & 1.14 & 0.39 \\
Rubber & 20 & 1.01 & 0.08 \\
Glass and cement & 57 & 0.99 & 0.40 \\
Steel & 59 & 0.99 & 0.21 \\
Non-ferrous metals & 89 & 0.98 & 0.09 \\
Machinery & 158 & 0.98 & 0.20 \\
Electrical machinery & 153 & 1.00 & 0.36 \\
Shipbuilding & 10 & 1.03 & 0.15 \\
Automobile & 53 & 1.02 & 0.32 \\
Other transportation & 18 & 0.99 & 0.28 \\
Precision machinery & 30 & 1.03 & 0.27 \\
Other manufacturing & 40 & 1.05 & 0.36 \\
\hline
\end{tabular}

use price level for goods in the corresponding industry since most industries purchase substantial quantities of inputs from their own industry.

We estimate the production function using data for 1977 to 1989 (the longest period for which data are available for the 1070 firms) and measure productivity as the 1989 regression residual associated with each firm. We calculate two sets of residuals-RES5 and RES2-based on whether we estimate the factor coefficients at the 5-digit or 2-digit level. The former method provides more degrees of freedom whereas the latter allows more variation in the estimated factor shares. ${ }^{4}$ We have the data to compute values of RES5 and RES2 for 1060 firms in 1989.

Table 2 provides information from the production function regressions where the factor elasticities vary across 2-digit industries. We show the industry name, number of

\footnotetext{
${ }^{4}$ Each 2-digit industry contains at least ten firms whereas 21 5-digit industries have five firms or fewer.
} 
firms, the returns to scale $\left(\mu=\beta_{M}+\beta_{K}+\beta_{S}+\beta_{U}\right)$, and capital's implied share of primary input costs $\left(\omega=\beta_{K} /\left(\beta_{K}+\beta_{S}+\beta_{U}\right)\right.$. The data reveal that constant returns to scale is not a bad assumption as $\mu$ ranges from 0.96 to 1.14 and only one industry (petroleum, 10 firms) has a $\mu$ that is more than 0.05 away from one. We note that simultaneity is likely to cause upward bias in estimates of factor shares so these values might be interpreted as upper limits. Petroleum exhibits the highest returns to scale and Textiles the least. The average implied capital share of primary inputs is .29 with 11 out of 17 industries having shares between .20 and .39 . There is more variation exhibited when we estimate the factor shares at the 5-digit industry level, a result partly due less precise estimates. In these regressions, one industry has $\mu=.76$ whereas it is between .88 and 1.18 for the remaining 87 industries. Capital's share of labour inputs has a mean of .33 (coincidentally equal to the value we used for ATFP) but a large standard deviation (.25) once we remove one 2-firm industry with a capital share of $-6.3 .^{5}$

We are not sure whether to take comfort in what Table 2 reveals about the estimates of the parameters of the industry production functions. Accounting data do not necessarily correspond well to the underlying economic variables in theoretical production functions and we must resort to use of book values of capital stocks instead of (usually unmeasurable) flows of capital services. This may result in inaccurate estimates. On the positive side, the results of roughly constant returns to scale and capital shares averaging around one-third appear plausible and indicate that ATFP may be a reasonable approximation.

\footnotetext{
${ }^{5}$ While there are no estimated negative factor shares when the coefficients vary at the 2-digit level, negative estimates do occasionally arise for 5-digit industry regressions. None of the negative estimates are statistically significant when we compute standard errors that allow for correlated errors at the firm level.
} 
Pavcnik (2002) deals with the endogeneity of input choices using a method due to Pakes and Olley (1995). Her method also treats potential biases due to non-random selection of the firm-level sample. This multi-step method uses polynomial approximations to back out innovations in productivity from the firm's investment decisions. Our concern here is not with production function estimation per se but rather with obtaining a measure of productivity that allows us to order firms in an industry. We believe that standard productivity estimation techniques are adequate for this purpose. In the analysis that follows, we subtract the industry mean level of productivity from firm productivity, a procedure that will alleviate some sources of potential bias in our estimates. We believe the principle shortcoming of our productivity estimates derives from the data and cannot be greatly reduced by more complex econometric methods that appear to make strong identifying assumptions. ${ }^{6}$

Table 3: Pairwise correlations between productivity measures

\begin{tabular}{lccccc}
\hline & ATFP & RES5 & RES2 & Ln sales & Ln VA \\
RES5 & 0.65 & & & & \\
RES2 & 0.71 & 0.84 & & & \\
Ln domestic sales & 0.27 & 0.14 & 0.14 & & \\
Ln domestic VA & 0.36 & 0.24 & 0.23 & 0.90 & \\
Ln employment & 0.10 & 0.05 & 0.05 & 0.92 & 0.88 \\
\hline Note: RES5 and RES2 are residuals from production function \\
estimates for 5- and 2-digit industries over the period 1977- \\
1989. "Domestic" sales and VA exclude export sales. All vari- \\
ables expressed as deviations from 5-digit industry averages.
\end{tabular}

Table 3 displays the correlations of the productivity measures. The size measuressales, value added, and employment—are logged and all variables are expressed as dif-

\footnotetext{
${ }^{6}$ See discussion in Syverson (2001).
} 
ferences from the relevant 5 -digit industry average. ${ }^{7}$ Thus, they reflect productivity differences within individual industries. The table reveals that all the measures are positively correlated. The "size" variables are highly correlated as one may expect. The productivity measures are highly correlated with each other ( $\rho$ 's between .65 and .84 ) but not highly correlated with the size measures. These low correlations $(0.05-0.27)$ do not square well with the model of HMY or with the general prediction that market equilibrium should give higher market shares to more efficient firms. One possible explanation is that firms in the same industry with very different measured productivities may actually be producing goods that are not close substitutes for each other. Even our 5-digit industries (shown in appendix) often aggregate over diverse sets of products.

In the following section, we see how the different measures of productivity vary across our groupings of firms.

\subsection{Results}

An important conceptual issue for the empirical analysis is how to utilize information for 88 5-digit industries. The theory outlined previously considers a single industry where each firm in the industry potentially sells into a number of foreign countries. The most productive firms do FDI, the least productive firms do not serve foreign consumers, and intermediate productivity firms export.

One problem is that productivity measures are not commensurate across industries. Monetary output measures and corresponding productivity residuals depend on the

\footnotetext{
${ }^{7}$ The residuals calculated using 5-digit factor share coefficients have zero means within 5-digit industries because we include a constant. All other measures have non-zero industry means prior to our "demeaning" procedure.
} 
price or unit of measurement of the industry. Employment may vary systematically across industries as a result of differences in minimum efficient scale. Some type of normalization is necessary before we can aggregate the information across the industries. Our technique is to subtract of the industry mean for each 5-digit industry so that productivity is represented as a difference from the industry average. This procedure forces each industry to have the same mean productivity (zero).

A second problem results from the limited number of firms in some industries industry. The number of firms ranges from two to 46 . The appendix shows the types of firms in each industry and reveals that only 15 industries have firms of each type (D, DX, DXI, DI). Seven industries only have firms of a single type whereas the rest have two or three types.

To see what issues this heterogeneity raises, consider the fictitious data contained in Table 4. Each cell corresponds to the average, demeaned productivity level of firms of the specified type in the specified industry. Assuming the same number of firms in each cell, average productivity in each industry is zero (as can be seen by summing down each column). The example follows the productivity ordering predicted by the theory. Averaging firm types across industries as shown in the last column illustrates two problems. First, including industry 1 will bias the DXI average towards zero. Second, the pooling of industries causes DXI average productivity to exceed that of DI firms in this example.

In light of these issues, we evaluate the theoretical predictions in two ways. Our first method is to average productivity across industries with the same set of firm types. We separately examine the 24 industries with DX and DXI firms, the 27 industries with D, 
Table 4: Aggregation issues

\begin{tabular}{lccccccc}
\hline \hline \multicolumn{7}{c}{ Industry } \\
\hline & 1 & 2 & 3 & 4 & 5 & 6 & Avg. \\
D & & & -7 & -10 & -9 & -1 & -6.75 \\
DX & & -1 & 3 & 4 & 2 & & 2 \\
DXI & 0 & 1 & 4 & 6 & 3 & & 2.8 \\
DI & & & & & 4 & 1 & 2.5 \\
\hline
\end{tabular}

DX, DXI firms, and the 15 industries with D, DX, DXI, and DI firms. Our second method is to code an ordered firm type variable and regress it on productivity measures. We assign D, DX, DXI, and DI firms the values 1,2,3, and 4. Heterogeneity in industry characteristics (fixed costs, trade costs, etc.) imply different relationships between productivity and firm type for each industry. We therefore estimate the regressions individually for each 5-digit industry.

Table 5 lists the mean characteristics of firms of each type for the three sets of industries. Recall the theory predicts a productivity ordering of D, DX, DXI, DI. The first column shows the number of firms of each type. The next three columns display means for the size proxies for productivity and the last three columns display means for the TFP variables. Recall that all the productivity measures are expressed as deviations from the 5-digit industry mean. The asterisks $\left({ }^{*}\right)$ identify cases where the mean for D, DXI, and DI firms differs significantly from that of DX firms (5\% level).

The means of the size variables across types strongly support the theory. D firms are $19 \%$ to $33 \%$ smaller than DX firms whereas DXI firms are 105\% to $332 \%$ larger than their DX counterparts. Moreover the differences between DXI and DX firms are statistically significant in each of the three sets of industries. One exception to the theory's 
Table 5: Average industry-demeaned productivity by firm type

\begin{tabular}{lrllllll}
\hline \hline & \# of & \multicolumn{3}{c}{ Size Variables } & \multicolumn{3}{c}{ TFP Variables } \\
& Firms & Ln Sales & Ln VA & Ln Emps. & ATFP & RES5 & RES2 \\
\hline \multicolumn{3}{c}{ 24 Industries with DX and DXI firms } \\
DX & 101 & -0.56 & -0.44 & -0.54 & -0.02 & -0.01 & -0.01 \\
DXI & 135 & $0.42^{*}$ & $0.39^{*}$ & $0.40^{*}$ & 0.02 & 0.01 & 0.01 \\
\hline \multicolumn{3}{c}{27 Industries with D, DX, and DXI firms } \\
D & 68 & -0.66 & -0.62 & $-0.67^{*}$ & -0.08 & 0.00 & 0.01 \\
DX & 179 & -0.42 & -0.41 & -0.35 & -0.03 & -0.02 & -0.02 \\
DXI & 157 & $0.77^{*}$ & $0.79^{*}$ & $0.69^{*}$ & $0.07^{*}$ & 0.02 & 0.02 \\
\hline \multicolumn{8}{c}{15 Industries with D, DX, DXI, and DI firms } \\
D & 69 & -0.58 & $-0.61^{*}$ & $-0.60^{*}$ & -0.08 & -0.01 & -0.01 \\
DX & 79 & -0.33 & -0.21 & -0.26 & 0.01 & 0.02 & 0.02 \\
DXI & 107 & $0.55^{*}$ & $0.51^{*}$ & $0.57^{*}$ & 0.03 & -0.01 & 0.00 \\
DI & 26 & $0.30^{*}$ & $0.23^{*}$ & 0.03 & 0.08 & -0.03 & -0.04 \\
\hline \hline
\end{tabular}

Note: ${ }^{*}$ indicates statistically significant $(5 \%)$ differences from DX firms.

predictions is that DXI firms appear more productive than DI firms (although DI firms are more productive than D and DX firms). This latter group is small-26 firms-and seems a bit unusual in that it comprises firms that invest abroad but do not export. The largest firms in this group are Toppan Printing, Snow Brand Milk Products, and Nippon Meat Packing. These firms produce goods that may be difficult to transport and hence are not exported.

The ordering of firm types based on the TFP estimates is mixed. Approximate total factor productivity, ATFP, orders firms exactly as theory predicts. However, the differences are small—for example, DXI firms are $4 \%-10 \%$ more productive than DX firmsand tend not to be statistically significant. In the case of RES2 and RES5, DXI firms are slightly more productive than other firm types in the top two panels. In the third panel, showing industries with all four types of firms, no ordering of RES2 and RES5 across firms types is apparent. 
Table 6: Ordered Type Regressions

\begin{tabular}{lccc}
\hline \hline Productivity Measure & \# Positive & \# Negative & Stacked \\
& $\mathrm{A}$ & $\mathrm{B}$ & $\mathrm{C}$ \\
Ln Sales & 75 & 6 & 0.325 \\
& $(32)$ & $(0)$ & $(0.023)$ \\
Ln VA & 69 & 9 & 0.289 \\
& $(25)$ & $(0)$ & $(0.025)$ \\
Ln emps & 73 & 8 & 0.344 \\
& $(35)$ & $(0)$ & $(0.023)$ \\
ATFP & 53 & 28 & 0.317 \\
& $(7)$ & $(0)$ & $(0.075)$ \\
RES5 & 50 & 31 & 0.051 \\
& $(0)$ & $(2)$ & $(0.157)$ \\
RES2 & 49 & 32 & 0.062 \\
& $(2)$ & $(2)$ & $(0.137)$ \\
\hline \hline Note: Numbers in parenthesis report the number of $t$ val- \\
ues greater than 2 in columns A and B and standard errors \\
in column C.
\end{tabular}

Table 6 summarizes the results of the ordered type regressions where the dependent variable assigns values of $1-4$ to the firm types D, DX, DXI, and DI. The explanatory variables are the alternative measures of productivity. These regressions could be estimated using ordered probit. This would have the desirable feature of allowing each firm type to obtain its own cutoff parameter. However, many of our industries do not have a sufficient number of firms to obtain reliable estimates of the coefficient on productivity while simultaneously estimating multiple cutoff parameters. Therefore, we use ordinary least squares which can be interpreted as a linear probability model.

The first column of Table 6 shows the number of cases where we estimate a positive coefficient on the productivity variable. The number of significant (at $5 \%$ level in a two-sided $t$ test) positive coefficients is shown directly underneath in parentheses. The second column provides corresponding information for negative coefficients. The re- 
sults for the size variables (sales, value added, and employment) strongly support the theory. The vast majority of the estimates are positive and many are significant. Negative estimates, when they obtain, are never significant. The evidence is much more mixed for the TFP variables (ATFP, RES5, and RES2). While the estimates tend to be positive, they are rarely significant and occasional negative and significant estimates obtain. The last column shows results where we stack industries and estimate a single coefficient for productivity with standard errors listed in parenthesis. The estimates are positive, significant and similar in magnitude for sales, value added, employment, and ATFP. The estimates for RES5 and RES2 are positive but much smaller and statistically insignificant. $^{8}$

Overall, we find some support for the predictions of the theory with the results for the size proxies being much stronger than those for the productivity estimates. Firms that only serve the domestic market tend to be less productive than firms that export and firms that do FDI. Investors who also export are generally more productive than exporters who do not have overseas investment. The theory suggests that firms that have overseas investment but no exports should be most productive. This prediction is not supported. What we have referred to as "the theory" is actually a special case of a more general model. In the next section we show that relaxing key assumptions can lead to quite different predicted orderings.

\footnotetext{
${ }^{8}$ Estimates of the stacked ordered type regressions using ordered probit gave a very similar pattern of $t$ statistics for the different size and TFP variables.
} 


\section{Extending the Model}

The previous analysis assumed equal wages in the home and foreign market, thus negating any "factor-seeking" motive for FDI. It also abstracted from considering the home market by assuming that the firm maintains its home plant to serve home-country consumers. In this section we investigate how robust the theoretical predictions are to these assumptions. We begin by considering wages differences across countries. Then we allow for the possibility of shutting down the home plant and using the foreign plant to serve home consumers.

\subsection{Wage differences}

The productivity of investing firms exceeds that of investing firms because, as shown in Figure 1, the FDI profit function is lower than the export profit function for low productivity levels but rises more quickly with increases in productivity. As shown in the paper, with identical marginal costs (equal to $w$ ) these profits functions are:

$$
\begin{aligned}
& \pi_{X}=[(1-w / A-\tau) / 2]^{2}, \\
& \pi_{I}=[(1-w / A) / 2]^{2}-K .
\end{aligned}
$$

The ratio of the slope of the FDI profit function, $\partial \pi_{I} / \partial A$, to the slope of the export profit function, $\partial \pi_{X} / \partial A$, exceeds one:

$$
\frac{1-w / A}{1-w / A-\tau}>1
$$


An intersection of the $\Pi_{X}(A)$ and $\Pi_{I}(A)$ curves must exist since profits of FDI rise faster than profits of exporting as productivity increases as long as the fixed costs of FDI make $\Pi_{I}(A)<\Pi_{X}(A)$ for low $A$. Now consider different wage costs in the foreign country equal to $w_{f}=w_{h}+\epsilon$. The ratio of the slopes can now be expressed as

$$
\left[\frac{1-w_{h} / A-\epsilon / A}{1-w_{h} / A-\tau}\right]\left[\frac{w_{h}+\epsilon}{w_{h}}\right] .
$$

For FDI to be the desired alternative for any productivity level, $\epsilon / A$ must be less than $\tau$ (given a positive fixed cost of FDI, the marginal cost disadvantage associated with producing abroad, $\epsilon / A$, must be smaller than the per unit transport cost savings of FDI, $\tau)$. Inspection reveals that for $0<\epsilon<A \tau$, the ratio of the slopes exceeds one. However, for $\epsilon<0$ the ratio may fall below one, thereby admitting the possibility of multiple intersections of the profit functions. Thus, as long as the foreign wage is no lower than the home wage, the result that investors are more productive than exporters holds under the assumption that the home plant continues to operate.

\subsection{Single-plant operations}

If the fixed costs of operating a plant are high and production costs are low in the foreign country, a firm will prefer to close its home plant and serve its home customers by importing from the foreign plant. For example, Sony could produce televisions in a low-wage country such as Malaysia and shut down television production in Japan. In this section, we consider this possibility and its implications for firms with different productivity levels. 
In general, the location of the single plant (in the home or foreign country) depends on relative costs and market sizes in each country. All firms prefer to locate in a lowcost country that has a large market. Thus, the interesting cases occur when one country offers a large market and another country offers low production costs (wages). Firms with different productivity levels may evaluate this tradeoff differently.

We define three alternative configurations of international production. Strategy $H$ denotes single-plant production in the home market with exports to the foreign country. Strategy $R$ (replication) involves production in both countries. Each plant serves local consumers and no exporting occurs. These are the two strategies we have already considered. The third strategy, $F$, entails production in the foreign country with exports back to the home country to serve consumers there. Firms prefer $F$ when fixed costs of production are high and the foreign country offers a large market or low wages. The decision to access low costs abroad may be termed factor-seeking FDI. Strategies $R$ and $F$ both involve investment abroad whereas strategy $H$ involves exporting from home.

To allow for differences in market size, we consider $M_{h}$ consumers in the home country and $M_{f}$ consumers in the foreign country, each with demand $q=1-p$. Wages at home and abroad are $w_{h}$ and $w_{f}$. Fixed costs are $K_{h}$ and $K_{f}$.

As before, we assume that productivity transfers to foreign operations. The profit functions associated with each strategy are

$$
\begin{aligned}
& \Pi_{H}=M_{h}\left[\left(1-w_{h} / A\right) / 2\right]^{2}+M_{f}\left[\left(1-w_{h} / A-\tau\right) / 2\right]^{2}-K_{h}, \\
& \Pi_{F}=M_{h}\left[\left(1-w_{f} / A-\tau\right) / 2\right]^{2}+M_{f}\left[\left(1-w_{f} / A\right) / 2\right]^{2}-K_{f},
\end{aligned}
$$




$$
\Pi_{R}=M_{h}\left[\left(1-w_{f} / A\right) / 2\right]^{2}+M_{f}\left[\left(1-w_{f} / A\right) / 2\right]^{2}-K_{h}-K_{f} .
$$

Firms choose the strategy that yields the highest profits and the choice depends on relative market sizes, marginal production costs, transport costs, and fixed costs. We are interested in whether our previous result that more productive firms choose FDI continues to hold.

We illustrate different outcomes in Figure 2. Since there is no interaction between fixed costs and productivity in the model, we set $K_{h}=K_{f}=K^{9}$ In order for the smaller of the two countries to be competitive, it must offer lower wages. The top two panels consider the case where the foreign market is big, but high cost. The lower panels depict the case where the foreign market offers low costs, but a small market. The two left panels assume high fixed costs $(K=.05)$ relative to the situation depicted in the right panels $(K=.045) .{ }^{10}$ The vertical axis measures the profits of FDI less the profits of home production. FDI can involve two-plant production $(R)$ or single-plant production abroad and exports back to home $(F)$. Each panel contains two curves that plot the $R$ or $F$ profits minus $H$ profits for different levels of productivity. The firm chooses the more profitable FDI alternative unless both are negative, in which case, a firm prefers $H$, home production and exporting.

The top panels show that high productivity firms prefer FDI to exporting from home when foreign wages are high. We already established the result depicted by the $\Pi_{R}-\Pi_{H}$ curve in the two figures when we showed the (replication) FDI profit function rises more

\footnotetext{
${ }^{9}$ Differences in fixed costs would not affect the relative incentive for firms with different productivity to choose one strategy or another.

${ }^{10}$ To generate the figures, we assume that transport costs equal .1 , the larger country has $M=2$ and $w=1$, and the smaller country has $M=1$ and $w=.9$.
} 
(a)

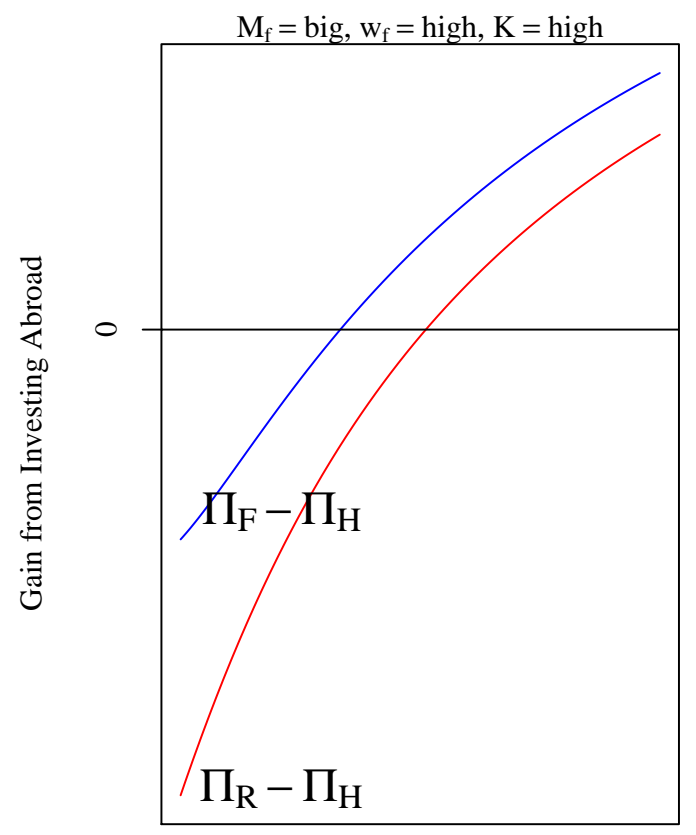

Productivity (A)

(c)

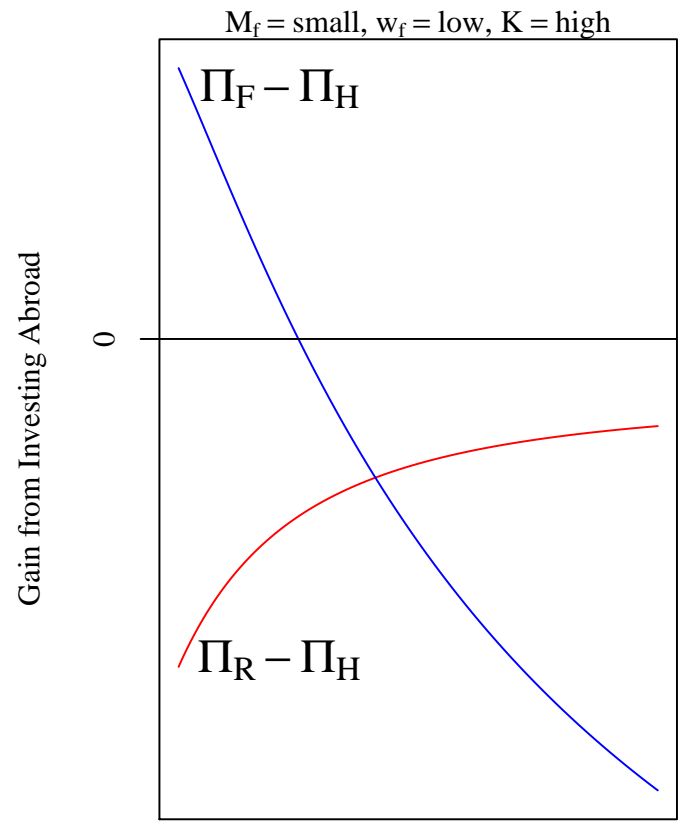

Productivity (A) (b)

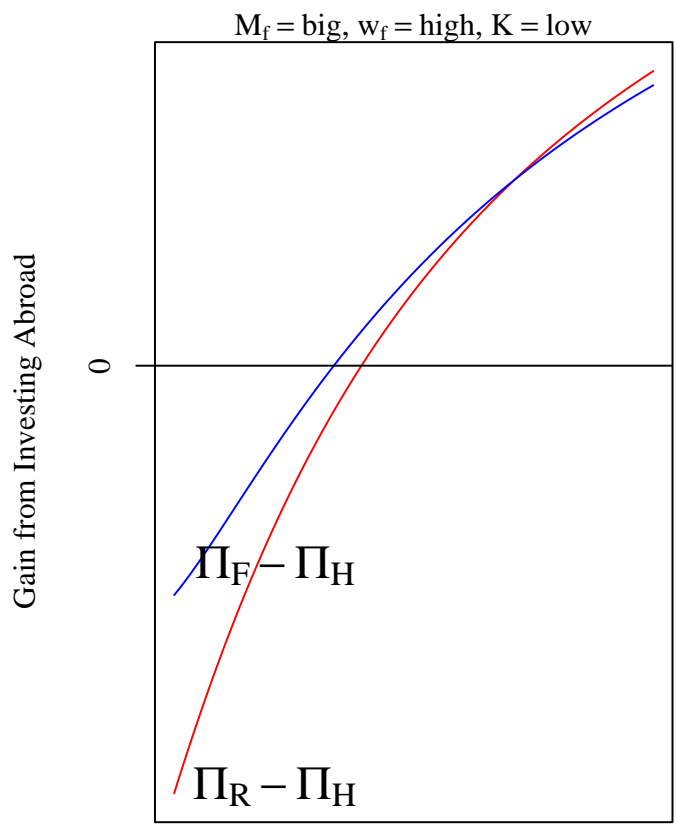

Productivity (A)

(d)

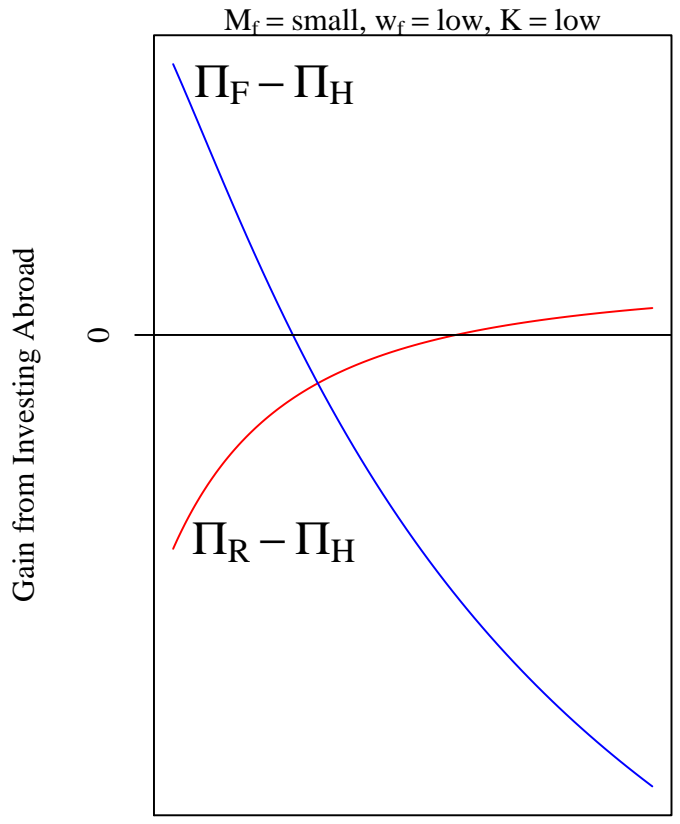

Productivity (A)

Figure 2: FDI versus exporting when host countries are heterogenous in size and wages 
quickly than the exporting profit function as productivity increases. This implies that high productivity firms are more likely to engage in replication $F D I$ and the figures bear this out. We have not previously considered, however, the possibility of shutting down the home plant. The $\Pi_{F}-\Pi_{H}$ curve shows that this is more profitable than $H$ for highly productive firms. In this case, the productive firms find it relatively more desirable to locate in the large market even at the expense of higher production costs. In the left panel, high fixed costs make single-plant production dominate two-plant production for all productivity levels. In the right panel, the most productive firms choose $R$ over $F$.

The lower two panels show that the results change dramatically when the foreign market is low cost. In the left panel, we set fixed costs at a high enough level to make replication undesirable regardless of firm productivity. The panel shows that $F$ can be more profitable than $H$ but only for the least productive firms. These firms find it most attractive to take advantage of low costs abroad at the expense of incurring trade costs to serve the large market. In the right panel, fixed costs are low enough to make replication the preferred strategy for highly productive firms. Here the least and most productive firms choose FDI, with the least productive firms choosing $F$ and the most productive firms choosing $R$.

\subsection{Testing an implication of the extended model}

Figure 2 indicates that the type of firm that chooses FDI depends on characteristics of the host country. When the host country offers a large market but has high wages, unproductive firms are unlikely to choose FDI. However, when the foreign country offers 

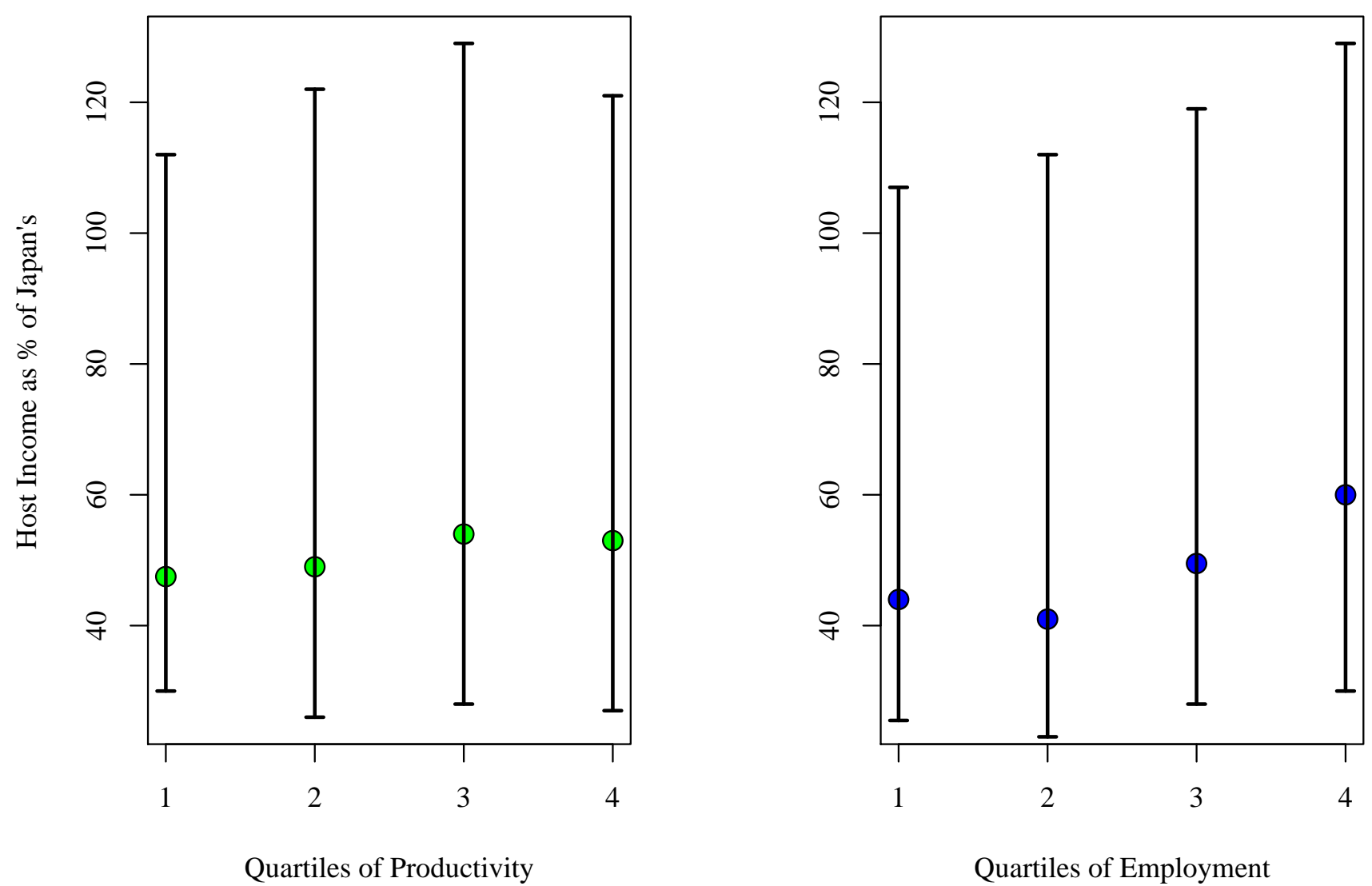

Figure 3: Medians and interquartile ranges for host income related to quartiles of firm productivity and size

low wages, both productive and unproductive firms may do FDI. This suggests that we should observe low productivity firms operating in low-wage countries but not in highwage countries while high productivity firms may invest in a wide range of countries.

To test this proposition, we consider DXI firms, those doing both FDI and exporting. ${ }^{11}$ We divide these 459 firms into quartiles (four equal-numbered groups) based on firm ATFP in panel (a) and employment in panel (b). We relate the productivity quartiles to the incomes (relative to Japan) of the host countries for the 2495 investments of these firms. Figure 3 shows the distribution of host income for the four quartiles of firms. The

\footnotetext{
${ }^{11}$ We exclude the $44 \mathrm{DI}$ firms since the fact that they never export implies very high transport costs, a possibility not represented in the figure.
} 
circles represent medians and the extensions show the 25th and 75th percentiles of the data.

We find some support for the extended version of the model. While interquartile ranges of host income are large for all quartiles of productivity, median and thirdquartile host incomes tend to rise in step with productivity. The relationship is stronger for employment than ATFP. Small firms only rarely invest in countries with higher incomes than Japan. The figure corroborates the theory's prediction that productive firms invest in a wider range of host countries.

\section{Conclusion}

In this paper we have investigated why firms in the same industry select different modes to reach foreign customers. Our paper complements the work of Helpman, Melitz, and Yeaple in three ways. First, we provide a very simple alternative model that yields the same predicted relationship between productivity and the decision to export or invest abroad. Second, we relax the assumption of equal wages and find that the productivity ordering can be reversed when the foreign market is the low-cost production site. Finally we examine productivity orderings using a sample of 1070 Japanese manufacturing firms.

Our empirical work shows that the relationship between productivity and the FDI versus export decision depends very much on the proxy used to measure productivity. Firm size measures exhibit a consistent ordering: firms that export are larger than firms that just serve the domestic market, but both types are smaller on average than 
firms that invest abroad as well as export. Production function residuals yield much weaker relationships with firm type. Orderings vary across samples and differences are uniformly small.

We find that heterogeneity in firm productivity appears to interact in important ways with heterogeneity in the market size and factor prices of potential host countries. These interactions underscore the importance of simultaneous consideration of firm and hostcountry differences in research on the FDI versus export decision. 


\section{Appendix: Industry information}

\begin{tabular}{|c|c|c|c|c|c|c|}
\hline Industry (5-digit) & \# Firms & Median Emps. & \# D & \# DX & \# DXI & \# DI \\
\hline \multicolumn{7}{|l|}{ Food } \\
\hline Feed & 5 & 472 & 4 & 0 & 0 & 1 \\
\hline Sugar & 9 & 133 & 5 & 2 & 0 & 2 \\
\hline Flour & 8 & 329 & 5 & 2 & 0 & 1 \\
\hline Oil & 8 & 168 & 6 & 0 & 2 & 0 \\
\hline Alcohol & 9 & 1818 & 1 & 3 & 4 & 1 \\
\hline Confections/Bread & 16 & 1436 & 8 & 3 & 2 & 3 \\
\hline Ham & 6 & 3620 & 2 & 0 & 0 & 4 \\
\hline Spice/Condiments & 10 & 694 & 4 & 1 & 4 & 1 \\
\hline Dairy & 6 & 3516 & 1 & 0 & 2 & 3 \\
\hline Other Food & 16 & 903 & 10 & 0 & 4 & 2 \\
\hline \multicolumn{7}{|l|}{ Textile } \\
\hline Synthetics & 6 & 5404 & 0 & 1 & 5 & 0 \\
\hline Cotton & 19 & 2225 & 5 & 3 & 11 & 0 \\
\hline Silk & 7 & 133 & 3 & 0 & 4 & 0 \\
\hline Wool & 9 & 426 & 4 & 1 & 2 & 2 \\
\hline Processed & 16 & 407 & 4 & 7 & 5 & 0 \\
\hline Other Textiles & 23 & 495 & 5 & 9 & 8 & 1 \\
\hline \multicolumn{7}{|l|}{ Pulp \& Paper } \\
\hline Major Paper & 5 & 5142 & 0 & 1 & 4 & 0 \\
\hline Pulp Paper & 26 & 634 & 10 & 9 & 6 & 1 \\
\hline \multicolumn{7}{|l|}{ Chemicals } \\
\hline Major Chemical & 7 & 5295 & 0 & 1 & 6 & 0 \\
\hline Fertilizers & 5 & 554 & 1 & 4 & 0 & 0 \\
\hline Soda/Chlorine & 7 & 2161 & 0 & 3 & 4 & 0 \\
\hline Petrochemicals & 2 & 3598 & 0 & 0 & 2 & 0 \\
\hline Synthetic Resin & 25 & 865 & 2 & 10 & 11 & 2 \\
\hline Oxygen & 8 & 617 & 2 & 3 & 3 & 0 \\
\hline Soap/Detergent & 8 & 779 & 0 & 3 & 5 & 0 \\
\hline Cosmetics/Toothpaste & 4 & 1952 & 1 & 0 & 3 & 0 \\
\hline Paint \& Ink & 15 & 728 & 0 & 1 & 10 & 4 \\
\hline Agric. Chems. \& Pesticides & 6 & 617 & 1 & 1 & 4 & 0 \\
\hline Other Chemicals & 46 & 568 & 3 & 27 & 16 & 0 \\
\hline \multicolumn{7}{|l|}{ Pharmaceuticals } \\
\hline Major Pharma. & 5 & 5979 & 0 & 0 & 5 & 0 \\
\hline Prescriptions & 20 & 2046 & 4 & 9 & 7 & 0 \\
\hline Non-prescriptions & 9 & 526 & 2 & 5 & 2 & 0 \\
\hline \multicolumn{7}{|l|}{ Petroleum } \\
\hline Refinery & 7 & 2412 & 2 & 4 & 1 & 0 \\
\hline Coal/Petrolum Products & 3 & 307 & 1 & 2 & 0 & 0 \\
\hline \multicolumn{7}{|l|}{ Rubber } \\
\hline Tires & 7 & 3556 & 2 & 0 & 5 & 0 \\
\hline Other Rubber & 13 & 848 & 2 & 6 & 5 & 0 \\
\hline
\end{tabular}




\begin{tabular}{|c|c|c|c|c|c|c|}
\hline Industry (5-digit) & \# Firms & Median Emps. & \# D & \# DX & \# DXI & \# DI \\
\hline \multicolumn{7}{|l|}{ Glass \& Cement } \\
\hline Glass & 7 & 1565 & 2 & 3 & 2 & 0 \\
\hline Cement I & 7 & 1646 & 2 & 1 & 3 & 1 \\
\hline Cement II & 14 & 467 & 8 & 0 & 5 & 1 \\
\hline Ceramics & 11 & 681 & 2 & 4 & 5 & 0 \\
\hline Bricks & 11 & 441 & 0 & 6 & 5 & 0 \\
\hline Carbon \& Others & 7 & 477 & 0 & 4 & 3 & 0 \\
\hline \multicolumn{7}{|l|}{ Steel } \\
\hline Integrated Steel & 8 & 20121 & 0 & 2 & 6 & 0 \\
\hline Electric Mills & 14 & 561 & 3 & 6 & 5 & 0 \\
\hline Special Steel & 7 & 2855 & 0 & 4 & 3 & 0 \\
\hline Amalgamated Steel & 5 & 674 & 0 & 4 & 1 & 0 \\
\hline Alloy Steel & 20 & 470 & 4 & 10 & 5 & 1 \\
\hline Stainless Steel & 5 & 1546 & 0 & 3 & 2 & 0 \\
\hline \multicolumn{7}{|l|}{ Non-Ferrous Metal } \\
\hline Major Refining & 8 & 3130 & 0 & 1 & 7 & 0 \\
\hline Other Metals & 5 & 538 & 1 & 2 & 1 & 1 \\
\hline Aluminum & 11 & 615 & 3 & 2 & 6 & 0 \\
\hline Electric Wires \& Cables & 14 & 883 & 1 & 6 & 7 & 0 \\
\hline Construction Metals & 14 & 576 & 7 & 6 & 1 & 0 \\
\hline Other Non-Ferrous Metals & 38 & 567 & 11 & 15 & 11 & 1 \\
\hline \multicolumn{7}{|l|}{ Machinery } \\
\hline Machine Tools & 30 & 756 & 2 & 14 & 14 & 0 \\
\hline Press Machines & 3 & 551 & 0 & 2 & 1 & 0 \\
\hline Textile & 10 & 645 & 0 & 8 & 2 & 0 \\
\hline Trans.,Construc. \& Combus. & 24 & 852 & 1 & 14 & 9 & 0 \\
\hline Agriculture & 7 & 703 & 2 & 3 & 2 & 0 \\
\hline Chemicals & 35 & 606 & 1 & 20 & 14 & 0 \\
\hline Sewing Machines/Looms & 4 & 2830 & 0 & 1 & 3 & 0 \\
\hline Rod Production Machinery & 12 & 1860 & 0 & 4 & 8 & 0 \\
\hline Office & 4 & 1089 & 1 & 1 & 2 & 0 \\
\hline Other Machinery & 29 & 543 & 6 & 15 & 8 & 0 \\
\hline \multicolumn{7}{|l|}{ Electrical Machinery } \\
\hline General Electronics & 4 & 58447 & 0 & 0 & 4 & 0 \\
\hline Turbines & 16 & 1275 & 0 & 7 & 9 & 0 \\
\hline Household Electronics & 29 & 1978 & 0 & 3 & 26 & 0 \\
\hline Communication & 30 & 1429 & 0 & 17 & 13 & 0 \\
\hline Electrical Parts & 24 & 1067 & 1 & 4 & 18 & 1 \\
\hline Control Machinery & 16 & 908 & 4 & 7 & 5 & 0 \\
\hline Battery & 5 & 1287 & 0 & 2 & 3 & 0 \\
\hline Auto-related & 4 & 4294 & 0 & 0 & 4 & 0 \\
\hline Other Electrical Machinery & 26 & 992 & 6 & 7 & 11 & 2 \\
\hline Shipbuilding & 10 & 3199 & 0 & 5 & 5 & 0 \\
\hline
\end{tabular}




\begin{tabular}{lrrrrrr}
\hline Industry (5-digit) & \# Firms & Median Emps. & \# D & \# DX & \# DXI & \# DI \\
\hline Automobile & & & & & & \\
Automobiles & 13 & 12616 & 1 & 2 & 10 & 0 \\
Parts & 35 & 1949 & 6 & 3 & 19 & 7 \\
Body/Others & 5 & 5103 & 0 & 2 & 3 & 0 \\
Other Transportation & & & & & & \\
Vehicles, Rolling Stocks & 4 & 1885 & 0 & 4 & 0 & 0 \\
Bicycles & 5 & 225 & 1 & 3 & 1 & 0 \\
Other Transportation & 9 & 808 & 2 & 2 & 5 & 0 \\
Precision Machinery & & & & & & \\
Clocks/Watches & 5 & 1388 & 0 & 2 & 3 & 0 \\
Camera & 8 & 3125 & 0 & 0 & 8 & 0 \\
Measuring Instruments & 17 & 817 & 0 & 11 & 6 & 0 \\
Other Manufacturing & & & & & & \\
Publishing & 8 & 917 & 4 & 1 & 2 & 1 \\
Musical Instruments & 2 & 8215 & 0 & 0 & 2 & 0 \\
Construction Material & 7 & 288 & 6 & 1 & 0 & 0 \\
Office Supplies & 6 & 1126 & 0 & 4 & 2 & 0 \\
Other Manufacturing & 17 & 800 & 4 & 6 & 7 & 0 \\
\hline \hline
\end{tabular}




\section{References}

Bernard, Andrew B. and J. Bradford Jenson, 1999, “Exceptional Exporter Performance: Cause Effect, or Both?" Journal of International Economics 47:1-25.

Bernard, Andrew B., Jonathan Eaton, J. Bradford Jenson, Samuel Kortum, 2003, “Plants and Productivity in International Trade," American Economic Review 93(4):12681290.

Brainard, S. Lael, 1997, "An Empirical Assessment of the Proximity-Concentration Tradeoff Between Multinational Sales and Trade," American Economic Review 87(4):520544.

Girma, Sourafel and Richard Kneller, 2003, "Export versus FDI: An Empirical Test," manuscript.

Griliches, Zvi and Jacques Mairesse, 1990, "R\&D and Productivity Growth: Comparing Japanese and U.S. Manufacturing Firms," Hulten, Charles, ed., Productivity Growth in Japan and the United States, Chicago: The University of Chicago Press.

Hall, Robert, and Charles Jones, 1999 "Why do Some Countries Produce So Much More Output per Worker than Others?," Quarterly Journal of Economics, 83-116.

Helpman, Elhanan, Marc J. Melitz, and Stephen R. Yeaple, forthcoming, "Export versus FDI with Heterogeneous Firms," American Economic Review and NBER Working Paper No. 9439.

Melitz, Marc J., forthcoming, "The Impact of Trade on Intra-Industry Reallocations and Aggregate Industry Productivity," Econometrica and NBER Working Paper No. 8881 .

Pakes, Ariel, and Steven Olley, 1995, "A Limit Theorem for a Smooth Class of Semiparametric Estimators," Journal of Econometrics 65, 295-332.

Pavcnik, Nina, 2002, “Trade Liberalization, Exit, and Productivity Improvements: Evidence from Chilean Plants," The Review of Economic Studies 69, 245-76.

Syverson, Chad, 2001, "Market Structure and Productivity: A Concrete Example" University of Chicago, manuscript.

Toyo Keizai, Inc., 1992, Japan Overseas Investment: A Complete Listing by Firms and Countries 1992/93, Tokyo. 